一短報——

\title{
めん羊・山羊の組織中の遊離アミノ酸とくにグルタミン 含量について
}

\author{
新林恒一・小原嘉昭
}

農林省家畜衛生試験場，小平市 187

(1977. 12. 23 受付)

現在, 反得動物に対する尿素飼料の給与は一定の条件 下では安全と考えられている11. 尿素中毒はすなわちつ ンモニフ中毒であり ${ }^{2-7)}$ ，中毒症状は血中アンモニアレ ベルに並行する ${ }^{6}$. 通常哺乳動物は体内での堂素代謝の 最終産物として肝で尿素を合成してフンモニフ解毒索す ることが知れている. 本報告では, 尿中排泄アンモニフ の給源はグルタミンであることに注目して，フンモニフ 解毒因子としてのグルタミンについて，他のアミノ酸パ ターンの関連から検討した.

\section{材料および方法}

使用動物はコリデール種めん羊 3 頭, ザーネン種山羊 4 頭および SPF 豚 $\left(H \times L, f_{1}\right) 25$ 頭であり，市販配合

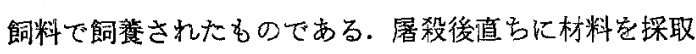
し，ドライアイスで湅結して分析に供した．分析部位は

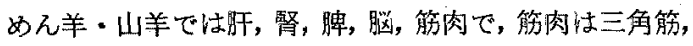
大腿二頭笳，背最長筋，また豚では肝，胸筋であった。

湿重量 $4 \mathrm{~g}$ の組織を $1 \%$ ピクリン酸 $29 \mathrm{ml}$ ととるに Waring blenderで均䓄化し, $1,500 \times g, 15$ 分遠心した. $26.4 \mathrm{ml}$ の上清船 Dowex $2, \times 8 \mathrm{Cl}$ 型 $(1 \times 5 \mathrm{~cm})$ 力ラ ムで脱ピクリン酸し，溶出液を湯浴上で $8 \mathrm{ml}$ に浱縮 した. その $4 \mathrm{ml}$ と $0.87 \mathrm{ml}$ の浱塩酸をガラス管中に 封じ, $115^{\circ} \mathrm{C}, 15$ 分加水分解した. 水解後，減压下で塩酸 它除き，元の $4 \mathrm{~m} l$ とした. 加水分解有亜の二者につい てアミ，酸分析行い8)，両者の傎からスレオニン，七 リン,フスパラギングルタミンを算出した．アミノ酸 濃度は組織の湿重 $100 \mathrm{~g}$ 当たりの mg で表わされた。

\section{結果および考察}

血漿遊離アミノ酸分析においてはグルタミンは, 不安
定なためその血中䟴度については余り注意が払われてい ないようである. また，本アミノ酸分析法ではグルタミ ンはスレオニンと，またアスパラギンはセリンと重なっ て溶出すること学予備実験で確め, それらの回収率索検 討した. その結果, グルタミンとアスパラギンの回収率 は，それぞれ約 80\%を 90\%であった。

めえ羊の各蔵器の遊離フミノ酸のパターン(表 1)它み ると，筋肉と他の諸蔵器とではかなりそのパターンが巽 なる. 著しい差がみられるのは, 筋肉ではメチルヒスチ ジンが高いこと，肝でフルギニンが低いことである.そ のほか,グルタミン酸は笳肉で低いが他の臟器では高く， ダリシンは肝, 书, 脾で高く, 笳肉, 脳では低かった。 た $\beta$-アラニンは筋肉の遊離アミノ酸画分加水分解し たとき高浱度に認められた。われわれがとくに興味家も った点は，肝ではグルタミン酸が高く，グルタミンが低 いのに反し，筋肉ではがルタミンがグルタミン酸よ自著 しく高いことである.めん羊にお河るこのような結果を 確めるために，山羊と豚について検討した。 その結果， 山羊ではダルタミン酸とダルタミンが, 肝ではをれでれ $114.2 \pm 12.5$ と $21.4 \pm 4.3 \mathrm{mg} / 100 \mathrm{~g}$ であるが、筋肉では逆

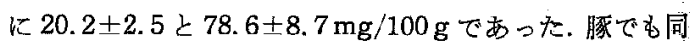
様に, 肝でそれぞれ $74.9 \pm 8.7$ と $10.0 \pm 1.5 \mathrm{mg} / 100 \mathrm{~g}$ あったのに，笳肉では $19.0 \pm 2.2$ と $68.6 \pm 7.9 \mathrm{mg} / 100 \mathrm{~g}$ であった。

物質代謝の旺盛な肝でのアンモニフの解毒は，主とし て尿索回路によって行れているが，この回路北関与する いくつかの化合物が，それぞれ他の代謝柔と密接に関連 して調節されている.他方，体重の約 $45 \%$ も占めている が尿素回路が働いていない觔肉組織において，グルタミ ン浱度が肝組織より著しく高いことは，フンモニて解毒

Observation of Free Amino Acids, especially Glutamine, in Various Tissues of Sheep and Goat:

Koichi Shimbayashi and Yoshiaki Obara (National Institute of Animal Health, Kodaira-shi 187)

日蓄会報， $49(6) ： 458-460$. 
組織遊離フミノ酸特にグルタミン

Table 1. Comparison of free amino acids among various tissues of sheep.

\begin{tabular}{|c|c|c|c|c|c|c|c|}
\hline & $\begin{array}{c}\text { M. del- } \\
\text { toideus }\end{array}$ & $\begin{array}{l}M . \text { longiss- } \\
\text { mus dorsi }\end{array}$ & $\begin{array}{l}M . \text { biceps } \\
\text { femoris }\end{array}$ & Liver & Kidney & Spleen & Brain \\
\hline Lys & 23.5 & 35.2 & 27.4 & 20.9 & 8.5 & 7.1 & 4.2 \\
\hline $\mathrm{m}$-His & 28.9 & 123.5 & 104.7 & 4.6 & 2.6 & $t$ & $\mathbf{t}$ \\
\hline His & 0.36 & $t^{*}$ & $t$ & 4.6 & 1.1 & 4.1 & 1.7 \\
\hline Arg & 5.0 & 2.7 & 3.3 & 0.9 & 4.0 & 4.0 & 2.3 \\
\hline Tau & 27.3 & 35.2 & 16.9 & 47.4 & 35.8 & 65.5 & 4.9 \\
\hline Asp & 1.3 & 1.5 & 0.59 & 50.9 & 15.0 & 30.6 & 24.9 \\
\hline Thr & 5.6 & 0.70 & 2.4 & 3.0 & 5.9 & 6.8 & 3.4 \\
\hline Ser & 4.3 & 2.4 & 2.7 & 6.0 & 6.0 & 7. 1 & 6.2 \\
\hline Glu & 15.2 & 2.6 & 4.4 & 85.5 & 75.3 & 109.0 & 99.5 \\
\hline Pro & 1.9 & $t$ & 0.94 & $t$ & 3.6 & 6.9 & $t$ \\
\hline Gly & 13.0 & 11.9 & 10.8 & 46.0 & 52.2 & 46.1 & 8.7 \\
\hline Ala & 29.6 & 14.4 & 16.3 & 15.7 & 9.7 & 10.9 & 6.0 \\
\hline Cys & 1.0 & 1.1 & 2.9 & 5.9 & 5.0 & 4.0 & 1.5 \\
\hline $\mathrm{Val}$ & 2.0 & 2.0 & 2.8 & 4. 2 & 4.6 & 8.0 & 5.3 \\
\hline Met & 0.34 & 0.12 & t & 1.2 & 0.92 & 1.6 & 0.24 \\
\hline Ile & 0.70 & 0.73 & 0.66 & 2.1 & 2.2 & 2.4 & 0.52 \\
\hline Leu & 1.1 & 1.1 & 1.1 & 3.2 & 5.0 & 8.0 & 1.2 \\
\hline Tyr & 1.3 & 1.7 & 1.2 & 2.5 & 3.1 & 3.2 & 1.2 \\
\hline Phe & 0.91 & 0.73 & 0.73 & 2.2 & 1.9 & 3.2 & 0.67 \\
\hline$\beta$-Ala & $\begin{array}{c}0.37 \\
(13.1)^{* * *}\end{array}$ & $\begin{array}{r}0.71 \\
(36.8)\end{array}$ & $\begin{array}{c}0.62 \\
(27.7)\end{array}$ & 2.9 & 2.0 & 1.3 & $\mathrm{t}$ \\
\hline Asn & 0.90 & 10.6 & 1.3 & 9.0 & 5.3 & 7.6 & 1.3 \\
\hline Gln & 107.9 & 40.7 & 63.4 & 13.4 & 7.4 & 8.1 & 52.9 \\
\hline
\end{tabular}

These values are expressed as $\mathrm{mg}$ per $100 \mathrm{~g}$ wet tissue weight. Each value is an average of 3 sheep. *t; trace, **( ); hydrolysate

にとって重要であると思われる，例えば体重粎 $40 \mathrm{~kg}$ の 山羊で, 筋肉の遊離ダルタミン浱度を約 $70 \mathrm{mg} / 100 \mathrm{~g}$ 上 すれば,グルタミンのアマイド-N は総量で $1.2 \mathrm{~g}$ になる 加ら，他の諸落器汃らのものを合的せれば，さらに多く なる.他方，同体重で血中尿素 $-\mathrm{N}$ が $10 \mathrm{mg} / 100 \mathrm{ml}$ の山 羊の尿素プールは，約 1〜2 $\mathrm{gN}$ であるといわれる9. 山 羊でのN出納实験において，楜曐白飼料給与時には，尿 中Nの的 $80 \%$ が尿素-N であるが，アンモニアーN はわ ずが数\%に過きず，さらに，グルタミンは排泄アミ， 酸中主たるものであったが，量的には尿素に比べて極め て少ないものであった。筒はグルタミナーゼ活性が高い ことが知られているが101，胙に比べてそのグルタミン含 量が低いことは，グルタミンの分解が盛んに行れている ことを反䀧しているものと思虬る。

フンモニアは高漕度であれば, 神経細胞や諸酵素の活

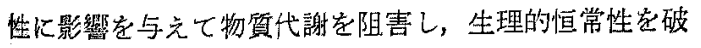
綻させる。しかしはがら，窒菜は生体にとって重要な元
素であり，とくに蛋白質代謝にとって重要である.生体 内で疗素は，ウレアーゼが存在しないためほとんど分解 されず，再循環の機構によってのみ利用されるので，肝

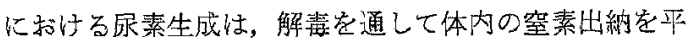
衡に遒くことに主たる意叙があると考えられる。他方， 筋肉におけるダルタミン酸とアンモニアからのグルタミ ンの合成注，フンモ二フの解毒と同時に大量に存在する グルタミン酸の酸性度を怪減し，利用可能な窒素とグル タミン酸の保持と供給の点に意議があると考えられる.

\section{文献}

1) OLtJen, R. R., Feed management, 23: 10.1972.

2) Dinning, J.S., M. H. Briggs, W. D. Gallup, H. W. OrR and R. Butler, Amer. J. Physiol. 153: 41-46. 1948.

3）広瀬可恒，北大農学部紀要 2：176-188，1954.

4) 中村亮八郎・吉田條二 - 堀込隆男 - 佐野修, 茨 城大学術報告，3：45-52. 1955 . 
5) Witson, R.P., L.E. Davis, M.E. Murrer and R. A. Bloomfield, Amer. J. Vet. Res., 29: 897906. 1968.

6）大森昭一朗・任藤 博，蓄試研報，26：9-24. 1973.

7) Itabisashi, T., Nat. Inst. Anim. Hlth Quart.,
16: 176-182. 1976.

8) Spackman, D. H., Stein, W. H. and Moore, S., Analyt. Chem., 30: 1190-1206. 1958.

9）小原嘉昭，栄䔗生理研究会報，20：18-29.1976.

10) Meister, A., Physiol. Rev., 36: 103-128. 1956. 